\title{
KLINIKINIS ATVEJIS: STIVENSO-DŽONSONO SINDROMAS
}

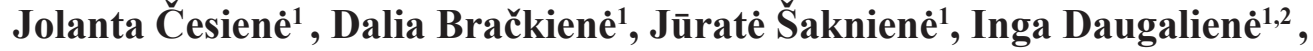 \\ Gabrielė Bružaité ${ }^{3}$, Egidijus Petraitis ${ }^{3}$ \\ ${ }^{1}$ Klaipédos universitetine ligonine, ${ }^{2}$ Vilniaus universiteto Medicinos fakultetas, \\ ${ }^{3}$ Lietuvos sveikatos mokslu universitetas
}

Raktažodžiai: Stivenso-Džonsono sindromas, toksinè epidermio nekrolizè, SCORTEN skalè, kortikosteroidai, imunoglobulinai.

\begin{abstract}
Santrauka
4 metų berniukui pirmają atvykimo ị ligoninę dieną pagal būdingus ligos simptomus ir požymius buvo nustatytas Stivenso-Džonsono sindromas. Priežastis liko neidentifikuota. Ligos baigtis buvo gera. Trumpai aptariame ši klinikini atvejị ir palyginame su literatūroje pateiktais mokslinių tyrimų duomenimis.
\end{abstract}

\section{Ivadas}

Stivenso-Džonsono sindromas/toksinė epidermio nekrolizè yra ūmi dermatozè, charakterizuojama epidermio atsiskyrimu bei ịvairios lokalizacijos gleivinių uždegimu, lydimu sisteminio sutrikimo (1).

Stivenso-Džonsono sindromas pasireiškia švelnesne forma, nei toksinė epidermio nekrolizè. Stivenso-Džonsono sindromas - būklè, kurios metu odos atsiskyrimas apima $<10$ proc. viso kūno paviršiaus. Gleivinès pažeidžiamos daugiau nei 90 proc. pacientų, dažniausiai keliose skirtingose lokalizacijose (akių, burnos bei lytinių organų gleivinèse). Toksinè epidermio nekrolizè pažeidžia daugiau nei 30 proc. odos paviršiaus. Odos pažeidimui apėmus nuo 10 iki 30 proc. viso kūno paviršiaus, konstatuojama Stivenso-Džonsono sindromo bei toksinès epidermio nekrolizès persidengiančioji forma (1).

Apskaičiuota, jog Stivenso-Džonsono sindromas/toksinè epidermio nekrolizė pasireiškia maždaug 1-2 atvejų milijonui gyventojų per metus (kai kuriais duomenimis iki 7 atvejų/ mln.) $(2,3)$.

Stivenso-Džonsono sindromas/toksinė epidermio nekrolizė yra charakterizuojama kaip plačiai paplitusi epitelio keratinocitų apoptozė ir nekrozė. Tai procesas, kurị dažniausiai inicijuoja vaistų paveikti citotoksiniai limfocitai (1).

Stivenso-Džonsono sindromo ir toksinès epidermio ne- krozès pasireiškimą dažniausiai lemia vaistų (ypač antibiotiku) vartojimas arba infekcija. Daugeliu atvejų pagrindinè ligos priežastis yra medikamentai. Nustatyta, jog toksinę epidermio nekrolizę daug rečiau sąlygoja infekcija nei Stivenso-Džonsono sindromą (3).

Dažniausi etiologiniai veiksniai: antibiotikai (sulfonamidai, penicilinas, cefalosporinai, tetraciklinas), prieštraukuliniai vaistai (fenobarbitalis, fenitoinas), nesteroidiniai vaistai nuo uždegimo.

Prodromo periodas pasireiškia karščiavimu, bendru silpnumu bei viršutinių kvejpavimo takų sutrikimu. Po keleto dienų atsiranda bẻrimas. Akių gleivinès uždegimas gali pasireikšti anksčiau nei pastebimi odos pokyčiai. Odos skausmas yra ankstyvas pastebimas Stivenso-Džonsono sindromo/ toksinès epidermio nekrolizès požymis. Anksčiausias odos pažeidimas - atipinès „taikinio“ dèmelès ir/arba purpurinès makulos. Paprastai pirminès pažeidžiamos vietos - viršutinė liemens dalis, proksimalinès galūnių dalys bei veidas. Vèliau odos pažeidimas apima dalį kaklo ir distalines galūnes. Delnuose ir paduose pasitaiko dažnai. Sunkesniais atvejais eritema susilieja ir užima vis didesnius odos plotus. Išberta oda tampa jautri lietimui. Net ir minimaliai tempiant pažeistą odos vietą, pažeistas epidermis lengvai nusilupa (teigiamas Nikolskio simptomas). Nikolskio simptomas nèra specifiškas Stivenso-Džonsono sindromui ar toksinei epidermio nekrolizei, tačiau kliniškai labai naudingas siekiant nustatyti epidermio nekrolizę. Pūslelès yra linkusios didèti, jungtis. Jų pikas pasiekiamas per 5-7 d. nuo pažeidimų odoje atsiradimo dienos. Pūslèms pratrūkus apsinuogina epidermio neapsaugotas dermos sluoksnis, kuris yra lengvas taikinys infekcijai $(1,4)$.

Stivenso-Džonsono sindromo diagnostikai dažniausiai užtenka klinikinio vaizdo. Nustatyti aiškią sindromo priežastị gali būti sunku, nes nèra jokio tam skirto specifiško laboratorinio tyrimo. Tokiu atveju reikia ịtarti bet kokị naujai skirtą ir vartotą vaistą 1-2 savaičių (kartais net 8 savaičių) laikotarpiu iki pirmujų Stivenso-Džonsono sindromo požy- 
mių atsiradimo (5). Reikia nepamiršti, kad panašų klinikini vaizdą gali sąlygoti infekcija, todèl siekiant atmesti virusinę ar bakterinę infekciją, verta atlikti serologinius (IgM ir IgG) ir PGR tyrimus . Galimi infekcijos sukèlejjai, pasireiškiantys panašia klinika: herpes simplex virusas (1 ir 2), varicellazoster virusas, citomegalo virusas, Epstein-Barr virusas, 6 ir 7 tipo žmogaus herpes virusas, parvovirusas ir M. pneumoniae $(1,5)$.

Diagnozuoti sindromą galima atlikus odos biopsiją. Mikroskopuojant bioptatą matomas epidermio nekrozès vaizdas, kurị lydi uždegiminè odos infiltracija $(1,2)$.

Nustačius Stivenso-Džonsono sindromą ar toksinę epidermio nekrolizę pirmiausia būtina nutraukti vaisto, galimai sukèlusio ligą, vartojimą. Atsižvelgiant ị ligos sunkumą, rekomenduojama pacientą gydyti nudegimų ar intensyvios terapijos skyriuje. I paciento gydymą įtraukiami įvairių sričių specialistai, siekiant išvengti komplikacijų ir suteikti kuo efektyvesni gydymą. Labai svarbų vaidmenį gydymo procese atlieka tinkama žaizdų priežiūra, skysčių, maistinių medžiagų balanso palaikymas, kvėpavimo funkcijos užtikrinimas, tinkamas nuskausminimas ir galimos infekcijos monitoravimas (1-3).

Dèl tinkamiausio gydymo diskutuojama, tačiau šiuo metu geriausiai kliniškai ištirta gydymo taktika, turinti teigiamą efektą, yra gydymas kortikosteroidais su ar be intraveninių imunoglobulinų terapija. Nesant kontraindikacijų, galima skirti trumpą kursą sisteminiais kortikosteroidais, vidutinèmis ar didelëmis dozèmis, t. y. 1-2 mg/kg per parą 3-5 dienas, pradedant ankstyvoje ligos fazeje per 24 - 48 valandas nuo simptomų atsiradimo (5). Sunkiais atvejais intraveninio imunoglobulino skiriama $1 \mathrm{~g} / \mathrm{kg}$ per parą 3 paras iš eilès, taip pat ankstyvoje ligos fazèje (6). Kiti gydymo metodai įtraukia gydymą ciklosporinu, plazmaferezę, TNF- $\alpha$ inhibitorius ar skirtingų vaistų kombinacijas. Gydymas antibiotikais turètų būti svarstomas tik tiems pacientams, kuriems kaip pagrindinè ligos priežastis yra ịtariama infekcija.

Per pirmas 24val. po paciento pristatymo ị gydymo ịstaigą, siekiant nustatyti sergančių toksine epidermio nekrolize komplikacijų riziką ir mirtingumą, sukurta ir plačiai naudojama speciali SCORTEN skaičiuoklè (1 ir 2 lentelès) $(1,7,8)$.

Bendras SDS/TEN mirtingumas siekia $25 \%$, apie $10 \%$ SJS atveju ir 30\% TEN atveju $(1,7,8)$. Dažniausios mirties priežastys - išsivystęs sepsis, ūminis kvėpavimo funkcijos distreso sindromas, daugybinis organų nepakankamumas.

Paciento gydymas gali užtrukti nuo kelių savaičių ir ilgiau, priklausomai nuo Stivenso-Džonsono ar toksinès epidermio nekrolizès išraiškos stiprumo, komplikacijų pasireiškimo. Neretai sveikstant formuojasi randinis audinys ligos pažeistuose plaukuotose odos srityse ir gleivinèse. Kaip liekamieji reiškiniai persirgus liga gali pasireikšti odos hipopigmentaciniai ar hiperpigmentaciniai pokyčiai, alopecija, anonichija, striktūros ar lètinès opos gleivinèse ar netgi sutrikusị regèjimą ar aklumą $(7,8)$.

\section{Klinikinis atvejis}

4 metų ir 10 mènesių amžiaus berniukas K.G. 2017 metų rugsèjo mėnesị hospitalizuotas ị Klaipèdos universitetinès ligoninès Reanimacijos ir intensyvios terapijos vaikų sektorių dèl staiga atsiradusio odos pakenkimo - pūslių atsiradimo ir išsivysčiusio skausminio šoko, Stivenso - Džonsono sindromo.

Pirmieji ligos požymiai: pūslès odoje pradejjo atsirasti 3 dienos iki hospitalizacijos, palaipsniui atsirado pūslių ir burnos gleivinèje. Pacientas konsultuotas PSPC, diagnozuotas pūlingas tonzilitas, gydytas ambulatoriškai, antibiotiko-

1 lentelè. SCORTEN balų skaičiuoklè

\begin{tabular}{|c|c|c|}
\hline Faktorius & Vertinimas & Balai \\
\hline Amžius & $\geq 40$ metų & 1 \\
\hline Piktybiškumas & Yra & 1 \\
\hline $\begin{array}{l}\text { Pažeistas kūno } \\
\text { paviršiaus plotas }\end{array}$ & $\geq 10 \%$ & 1 \\
\hline Tachikardija & $\geq 120 / \mathrm{min}$ & 1 \\
\hline $\begin{array}{l}\text { Šlapalo koncen- } \\
\text { tracija serume }\end{array}$ & $\geq 10 \mathrm{mmol} / 1$ & 1 \\
\hline $\begin{array}{l}\text { Gliukozės } \\
\text { koncentracija } \\
\text { serume }\end{array}$ & $\geq 14 \mathrm{mmol} / 1$ & 1 \\
\hline \multirow[t]{2}{*}{$\begin{array}{l}\text { Bikarbonatų } \\
\text { koncentracija } \\
\text { serume }\end{array}$} & $\begin{array}{c}<20 \\
\mathrm{mmol} / 1\end{array}$ & 1 \\
\hline & $\begin{array}{c}\text { Galima balų } \\
\text { suma }\end{array}$ & $0-7$ \\
\hline
\end{tabular}

2 lentelè. SCORTEN balų vertinimas

\begin{tabular}{|l|c|}
\hline $\begin{array}{l}\text { SCORTEN } \\
\text { balai }\end{array}$ & $\begin{array}{c}\text { Nuspėjamas } \\
\text { mirtingumas } \\
\text { procentais }\end{array}$ \\
\hline $\mathbf{0}$ & $1 \%$ \\
\hline $\mathbf{1}$ & $4 \%$ \\
\hline $\mathbf{2}$ & $12 \%$ \\
\hline $\mathbf{3}$ & $32 \%$ \\
\hline $\mathbf{4}$ & $62 \%$ \\
\hline $\mathbf{5}$ & $85 \%$ \\
\hline $\mathbf{6}$ & $95 \%$ \\
\hline $\mathbf{7}$ & $99 \%$ \\
\hline
\end{tabular}


terapija neskirta. Bėrimui išplitus, formuojantis vietomis susiliejančioms pūslèms, joms trūkinejjant ir dèl to intensyvẻjus skausmui, kreipèsi į Klaipėdos universitetinès ligoninès Infekcinių ligų departamento Prièmimo skyrių.

Atvykus vaiko būklè labai sunki. Fiksuota normali temperatūra. Apžiūrint vyravo skausminio šoko klinika. Viso kūno oda raudona, kūno odoje daugybė nusilupusių ir šlapiuojančių pūslių, besiformuojančios naujos. Stebimas lūpų patinimas, burnos gleivinès pažeidimas, ryklèje - nekrozinès masès. Akių vokai sutinę, junginès paraudusios. Prisilietimas prie kūno odos skausmingas. Kitos sistemos - normos ribose.

Atliktame bendraklinikiniame kraujo tyrime leukocitu skaičius normalus pagal amžių, stebèta saikinga eozinofilija (abs.sk. 0,77 x 109/1, norma 0,01-0,70 x 109/1), C - reaktyvus baltymas $5,43 \mathrm{mg} / 1$.

Hospitalizacijos eigoje atlikti serologiniai tyrimai galimam infekciniam agentui išaiškinti: $\mathrm{CMV} \operatorname{IgG}(+), \mathrm{HSV} 1$ ir2 $\operatorname{IgG}(+)$; imunologiniai tyrimai: ANA(-), ANCA(-). Rastas padidejjęs bendras IgE $290 \mathrm{KIU} / 1$ (normalus kiekis pagal amžių 0-60 IU/1), atlikti alergologiniai testai - rastas padidèjęs antikūnų titras dulkių erkutems ir katèms.

Remiantis ANG gydytojo išvadomis diagnozuotas ūminis tonzilitas ir abipusis išorinès ausies uždegimas, oftalmologo - ūminis konjungtyvitas, dermatologo ir alergologo konsultacijų išvada patvirtino Stivenso-Džonsono sindromo diagnozę.

Skausminio šoko gydymui taikytas nuskausminimas opoidiniais analgetikais - morfino infuzija. II kartos cefalosporinų antibiotikų priedangoje skirtas intensyvus gydymas intraveniniais gliukortikoidais, infuzoterapija. Esant teigiamam gydymo efektui palaipsniui pereita ị peroralinę gliukokortikoidoterapiją. Suminė GKS dozè sieké $925 \mathrm{mg}$.

Stacionarinio gydymo trukme 21 para: RITS - 16 parų, skyriuje - 5 paros.

Odai epitelizavusis ir sugijus gleivinèms pacientas išrašytas ambulatoriniam gydymui patenkinamos būklès. Gydymas peroraliniais gliukortikoidais užbaigtas per 1 savaitę prižiūrint šeimos gydytojui.

\section{Išvada}

Hipererginę organizmo reakciją (SDS) sukèlęs agentas liko nenustatytas. Gydymas intensyvios terapijos skyriuje ir taikyta gliukokortikosteroidų terapija buvo efektyvi. Laiku taikyto gydymo rezultatas: ligos baigtis be ilgalaikių liekamujų reiškinių.

\section{Literatūra}

1. Creamer. et al. U.K. guidelines for the management of StevensJohnson syndrome/toxic epidermal necrolysis in adults 2016. British Journal of Dermatology 2016; 174:1194-1227.

https://doi.org/10.1111/bjd.14530
2. Ferrandiz-Pulido C. et al. A review of causes of Stevens-Johnson syndrome and toxic epidermal necrolysis in children. Arch Dis Child 2013;98:998-1003.

https://doi.org/10.1136/archdischild-2013-303718

3. Narkevičiūtè I. ir kt. Lietuvos bendrosios praktikos gydytojas, 2008; 12(3):234-237.

4. Harr T, French LE. Stevens-Johnson syndrome and toxic epidermal necrolysis. Chemical immunology and allergy 2012;97:149-66.

https://doi.org/10.1159/000335627

5. http://oxfordmedicine.com.ezproxy.dbazes.1smuni.1t:2048/ view $/ 10.1093 / \mathrm{med} / 9780198527480.001 .0001 / \mathrm{med}-$ 9780198527480 -chapter-015? rskey $=\mathrm{NBhnWB} \&$ result $=1$. (2017 09 17).

6. http://www.mayoclinic.org/diseases-conditions/stevens-johnson-syndrome/symptoms-causes/syc-20355936. (2017 09 17).

7. Bansal S, Garg VK, Sardana K, Sarkar R. A clinicotherapeutic analysis of Stevens-Johnson syndrome and toxic epidermal necrolysis with an emphasis on the predictive value and accuracy of SCORe of toxic epidermal necrolysis. International Journal of Dermatology 2015; 54(1):18-26.

8. Beck A, Quirke KP, Gamelli RL, Mosier MJ. Pediatric toxic epidermal necrolysis: using SCORTEN and predictive models to predict morbidity when a focus on mortality is not enough. Journal of Burn Care and Research: Official Publication of the American Burn Association 2015; 36(1):167-77.

https://doi.org/10.1097/BCR.0000000000000204

\section{CLINICAL CASE REPORT: STEVENS-JOHNSON SYNDROME}

\section{J. Česienė, D. Bračkienė, J. Šaknienė, I. Daugalienė,} G. Bružaitè, E. Petraitis

Key words: Stiven-Johnsons syndrome, toxic epidermal necrolysis, SCORTEN scale, corticosteroids, imunoglobulines.

Summary. We present the clinical case of Stevens-Johnson syndrome. This diagnosis was established by evaluation typical symptoms and signs in the boy aged 4 years on the first day of hospitalization. The cause of the disease was not identified. The outcome of the disease was good. We discussed this clinical case and compared with the data in the scientific literature.

Correspondence to: jolantaces@hotmail.com

Gauta 2017-11-06 